\title{
Rapid Development of PLBs Derived from Immature Seeds and Mass Multiplication of Vanda tessellata (Roxb.) Hook. Ex G. Don - A Threatened Orchid species in Bangladesh
}

\author{
${ }^{1}$ Bakul Bhattacharjee, S. M. Shahinul Islam ${ }^{1 *}$ and Sreeramanan \\ Subramaniam ${ }^{2}$ \\ 1Plant Genetic Engineering Lab., Institute of Biological Sciences, University of Rajshahi, \\ Rajshahi-6205, Bangladesh \\ ${ }^{2}$ School of Biological Sciences, University Sains Malaysia (USM), Penang, Malaysia.
}

Key words: Rapid development, Medicinal orchids, Immature seeds, Regeneration

\begin{abstract}
A rapid and an efficient protocol for germination of immature seeds of Vanda tessellata, PLBs development and plant regeneration system have been developed. The results indicate that immature capsules performed better in terms of germination (100.0\%) and development of PLBs (90.0\%). Around $45-60$ days old PLBs were transferred to half strength of MS supplemented with different concentrations of auxins and cytokinins. The highest weight of PLBs $(5.53 \mathrm{~g})$, the best plant regeneration $(16.50)$ and shoot length $(3.25 \mathrm{~cm})$ were recorded when the medium was supplemented with BAP $(1.0 \mathrm{mg} \Lambda)$ and NAA $(1.5 \mathrm{mg} /)$. The highest number $(5.0)$ and length $(3.22 \mathrm{~cm})$ of roots, the maximum number of plantlets (3.75) were obtained in the medium supplemented with 1.5 $\mathrm{mg} / \mathrm{BAP}$ and $1.0 \mathrm{mg} / \mathrm{IAA}$. The maximum numbers of leaves (3.33) were recorded in the medium fortified with $1.5 \mathrm{mg} / \mathrm{BAP}+1.00 \mathrm{mg} / \mathrm{IAA}$; the highest length of leaves $(2.59 \mathrm{~cm})$ was observed in the medium combining with of BAP and IAA $(2.0 \mathrm{mg} /)$. Well shooted - and rooted plants were acclimated in pots that contained two types of compost. Here, type-II showed better performance on plant development.
\end{abstract}

\section{Introduction}

Vanda tessellata (Roxb.) Hook. Ex. G. is an epiphytic endangered medicinal and floricultural important orchid in Bangladesh. It is also a threatened medicinal

*Author for correspondence: <shahin_ibsc@ru.ac.bd>. 
plant belonging to Orchidaceae. It contains 800 genera and between 25,000 and 30,000 species spread all over the world (Singh et al. 2007, Chugh et al. 2009, Nongdam and Chongtham 2011). The plant contains an alkaloid, a glucoside, tannins, $\beta$-sitosterol, $\gamma$-sitosterol and a long chain aliphatic compound, fatty oils, resins and colouring matters. The roots of Vanda tessellata are antipyretic; useful in dyspepsia, bronchitis, inflammations, piles and hiccup and contain tetracosyl ferrulate and $\beta$-sitosterol-D-glucoside (Ghani et al. 1990). A novel aphrodisiac compound isolated from the flowers of Vanda tessellata (Roxb.), which activates neuronal and endothelial, but not inducible (Subramaniam et al. 2013). The agroclimatic conditions of Bangladesh are congenial for natural orchid vegetation in different regions especially in Chittagong Hills tracks, Rangamati, Sylhet and Sundarbans. There are about 115 different varieties of orchids are available in Bangladesh (Bhadra et al. 2002). Some species are endangered threatened with extinction and uncontrolled collection and habitat destruction have led also to drastic reduction in the number of orchids in the Indian subcontinent (Pradhan 1985, Kalimuthu 2007). Since 1970's, different biotechnological approaches e.g. in vitro micropropagation, genetic transformation, cryopreservation and hybridization techniques are widely used for orchid improvement (Antony et al. 2014). Those techniques are essential tools to meet the commercial demand and conservation of wild, rare and useful orchid species in the world. Pierik (1987) reported that an orchid plant produces 1,300 to 4 million seeds per capsule and only $0.2-0.3 \%$ germinate in nature (Singh 1992). Orchid seeds are very small and do not have a sufficient reserve food material to support the growth of embryos during germination. They depend on some external source for nutrients to help their undifferentiated embryos develop into a protocorm. The present work has been undertaken to study the effects of various media for seed germination, development of protocorm like bodies, their regeneration, mass multiplication of this species.

\section{Materials and Methods}

The immature capsules of Vanda tessellata used as seed source were collected from Rajshahi, Bangladesh. At first, the capsules were washed by running tap water and surface sterilized by detergent. Then capsules were treated with $0.2 \%$ $(\mathrm{w} / \mathrm{N}) \mathrm{HgCl}_{2}$ solution for $10 \mathrm{~min}$ and finally dipped in $70 \%$ ethanol for $10-12 \mathrm{sec}$. Then they were washed with sterile distilled water and sterilized capsules were cut longitudinally by a sterile surgical blade (Fig. 1a). Around $200 \mathrm{mg}$ seeds were cultured per vessel (Fig. 1b). Various media viz. MS, B5 (Gamborg et al. 1968) and PM (Phytamax ${ }^{\mathrm{TM}}$, Sigma, USA) were used in this study. The basal media (MS and B5) amended with $3 \%(\mathrm{w} / N)$ sucrose and the PM was amended with $2 \%$ 
$(\mathrm{w} / \mathrm{v})$ sucrose. The $\mathrm{pH}$ for all media was adjusted at 5.6 - 5.8. Inoculated vessels were maintained in the culture room under a period of $16 \mathrm{hrs}$ light and $8 \mathrm{hrs}$ dark at $25 \pm 2^{\circ} \mathrm{C}$. After two weeks of inoculation, a few seeds were taken out and dispersed in one drop of water on a glass slide and examined under a light microscope (Fig. 1c, d). Germination percentages were calculated employing the following formula:

No. of seeds showing swelling of the embryo $\times 100$

\section{No. of total seeds}

Once the spherules were formed, developmental stages of the protocorms were recorded every week up to 8 - 10 weeks. Then PLBs were transferred to $1 / 2$ MS supplemented with different concentration of auxins and cytokinins. Furthermore, regenerated plants were transplanted and grown outside the environment for ex vitro establishment; complete plantlets were recorded within 60 - 70 days of culture initiation. The well rooted plants were removed from the culture bottles and hardened successfully in clean plastic pots of $8.0 \mathrm{~cm}$ diameter containing different mixtures of compost viz., (i) brick and charcoal pieces $(1: 1)$, (ii) brick, charcoal and decaying litter (1:1:1), (iii) brick, charcoal, decaying litter and sawdust (1:1:1:1), (iv) brick, charcoal, decaying litter and coconut husk $(1: 1: 1: 1)$. All substrates were covered with a layer of $10.0 \mathrm{~g}$ sphagnum moss. The plantlets were watered in alternate evening and fed with MS nutrient salt solutions (diluted 10 times) fortnightly for about a month and eventually established under natural condition following the protocols of Das et al. (2007). On the basis of seed germination and its developmental stages, PLBs formation, regeneration, shoot and root developments were recorded. Each value represents an average of 10 replicates. Data were subjected to analysis of variance (ANOVA) and means were separated by DMRT.

\section{Results and Discussion}

Orchid seeds do not possess endosperm and that limits their germination in nature. Usually orchid seeds germinate in symbiotic association with some species - specific mycorrhiza, which supply food to the germinating undifferentiated orchid embryos (Rahman et al. 2009). In the present study, immature green pods were considered and four types of basal media (MS, 1/2MS, PM and B5) without PGRs were used to assess their effect on seed germination and PLBs formation. Among the basal media tested, MS was the most effective for germination and protocorms development (Table 1). The Highest percentage of seed germination was recorded in MS $(100.0 \%)$ followed by half strength of MS (90.0\%), PM (60\%) and B5 (45.0\%). It was observed that the germinated seeds 
Table 1. Effects of various media and different strength of growth regulators on seed germination and PLBs development in V.tessellata.

\begin{tabular}{lccccc}
\hline Media & $\begin{array}{c}\text { Amount of } \\
\text { seeds per } \\
\text { culture vessel }\end{array}$ & \multicolumn{2}{c}{ Seed germination } & \multicolumn{2}{c}{ PLBs development } \\
\cline { 2 - 5 } & $200 \mathrm{mg}$ & $30-35$ & $\begin{array}{c}\text { \% of } \\
\text { germination }\end{array}$ & Days & $\begin{array}{c}\% \text { of } \\
\text { protocorms }\end{array}$ \\
\hline MS & $200, "$ & $34-40$ & 100.0 & $35-40$ & 90.0 \\
$* 1 / 2$ MS & $200, "$ & $50-55$ & 60.0 & $40-50$ & 75.0 \\
PM & $200, "$ & $45-50$ & 45.0 & $60-65$ & 50.0 \\
B5 & & & & $50-55$ & 30.0 \\
\hline
\end{tabular}

*half strength of MS.
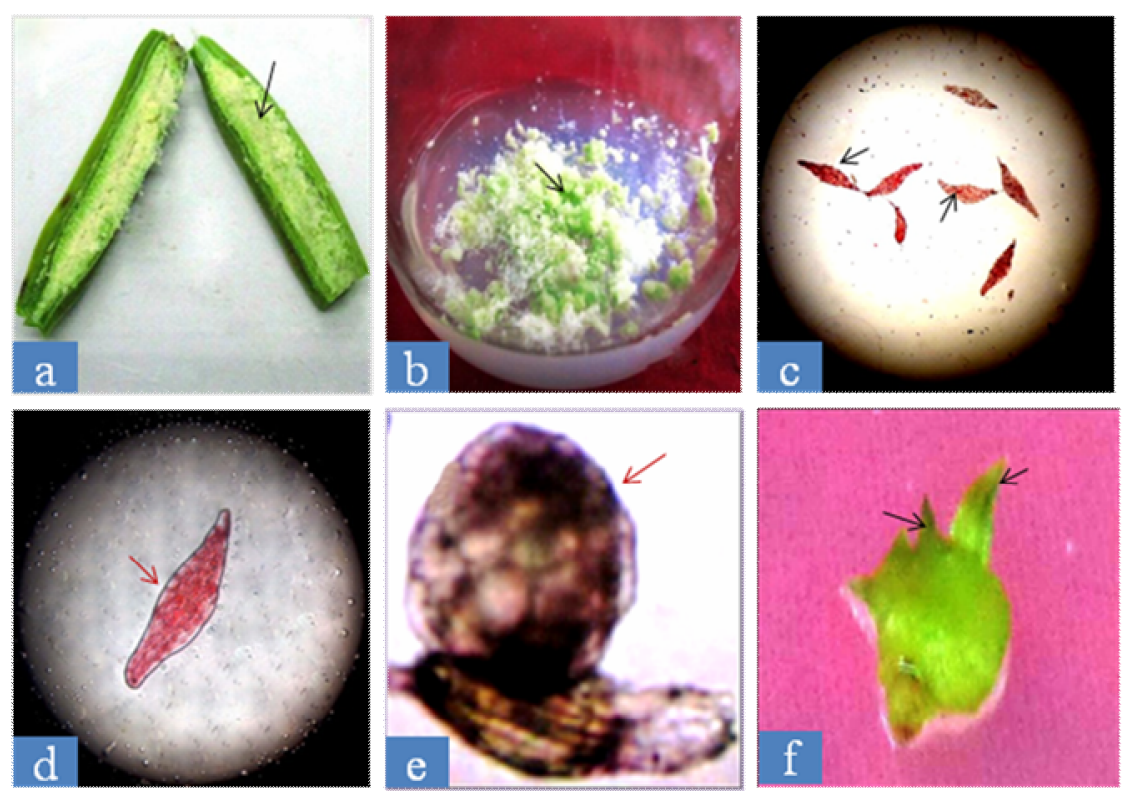

Fig. 1 (a - f): Seed germination of Vanda tessellata. a. Longitudinal dissection of immature capsule. b. Inoculated seeds into MS. c. Early stage of seed germination shown under light microscope $(10 \times 10)$. d. Single seed after one week of culture initiation that showing swelling of embryo. e. Parenchymatous cell mass coming out by rupturing test. f. A protocom with leaf primordia.

increased in size and highest protocorms (90.0\%) was recorded in MS (Fig. 1f, Table 1). After 25 days the protocorms were sub-cultured in the same medium. It was observed that in every stage of sub-culture the protocorms grew vigorously and number increased but their individual growth and development was not so satisfactory (Fig. 2b). In order to induce rapid growth and elongation, the protocorms were sub-cultured on half strength of MS supplemented with 
different concentrations of $\mathrm{BAP}, \mathrm{Kn}, \mathrm{NAA}$ and IAA. To promote the normal growth of the seedlings, the combination of NAA and BAP was better than other combinations of auxin and cytokinin (Table 2, Fig. 2c, d). Significant variation in weight of PLBs was recorded with various combinations of plant growth regulators of $\mathrm{BAP}+\mathrm{Kn}, \mathrm{BAP}+\mathrm{NAA}$ and $\mathrm{BAP}+\mathrm{IAA}$. In case of $\mathrm{BAP}+\mathrm{Kn}$, the

Table 2. Effect of growth regulators on the development of PLBs of V. tessellata at 60 days after inoculation in $1 / 2$ MS.

\begin{tabular}{lllll}
\hline PGRs & $\begin{array}{l}\text { Concentration } \\
(\mathrm{mg} /)\end{array}$ & $\begin{array}{l}\text { Wt. of } \\
\text { PLBs }(\mathrm{g})\end{array}$ & $\begin{array}{l}\text { Regenerated } \\
\text { plantlets }\end{array}$ & $\begin{array}{l}\text { Length } \\
\text { of shoot }(\mathrm{cm})\end{array}$ \\
\hline \multirow{3}{*}{ BAP + Kn } & $0.5+0.5$ & $2.56^{\mathrm{b}}$ & $11.33^{\mathrm{ab}}$ & $1.17^{\mathrm{b}}$ \\
& $1.0+1.5$ & $3.72^{\mathrm{a}}$ & $12.33^{\mathrm{a}}$ & $2.39^{\mathrm{a}}$ \\
& $1.5+1.0$ & $4.01^{\mathrm{a}}$ & $12.67^{\mathrm{a}}$ & $1.14^{\mathrm{b}}$ \\
& $2.0+2.0$ & $4.08^{\mathrm{a}}$ & $10.33^{\mathrm{b}}$ & $1.36^{\mathrm{b}}$ \\
& $0.5+0.5$ & $3.74^{\mathrm{c}}$ & $12.6^{\mathrm{b}}$ & $1.63^{\mathrm{b}}$ \\
BAP + NAA & $1.0+1.5$ & $5.53^{\mathrm{a}}$ & $16.50^{\mathrm{a}}$ & $3.25^{\mathrm{a}}$ \\
& $1.5+1.0$ & $4.94^{\mathrm{b}}$ & $13.88^{\mathrm{b}}$ & $2.00^{\mathrm{b}}$ \\
& $2.0+2.0$ & $5.38^{\mathrm{a}}$ & $12.75^{\mathrm{b}}$ & $2.20^{\mathrm{b}}$ \\
& $0.5+0.5$ & $2.78^{\mathrm{a}}$ & $11.43^{\mathrm{b}}$ & $1.75^{\mathrm{a}}$ \\
BAP + IAA & $1.0+1.5$ & $3.33^{\mathrm{ab}}$ & $13.14^{\mathrm{a}}$ & $2.27^{\mathrm{a}}$ \\
& $1.5+1.0$ & $3.68^{\mathrm{b}}$ & $13.00^{\mathrm{a}}$ & $2.10^{\mathrm{a}}$ \\
& $2.0+2.0$ & $4.10^{\mathrm{c}}$ & $11.71^{\mathrm{ab}}$ & $2.10^{\mathrm{a}}$ \\
\hline
\end{tabular}

Means in a column with the different letters (superscripts) are significantly different according to DMRT at $\mathrm{p}<0.05$ levels.

highest weight $(4.08 \mathrm{~g})$ of PLBs found in BAP $(2.0 \mathrm{mg} /)+\mathrm{Kn}(2.0 \mathrm{mg} /)$ and lowest $(2.56 \mathrm{~g})$ from $0.5 \mathrm{mg} \wedge \mathrm{BAP}+0.5 \mathrm{mg} \Lambda \mathrm{Kn}$. In case of BAP + NAA, the highest weight $(5.53 \mathrm{~g})$ of PLBs was obtained from $1.0 \mathrm{mg} / \mathrm{BAP}+1.5 \mathrm{mg} / \mathrm{NAA}$ and lowest $(3.74 \mathrm{~g}$ ) from $0.5 \mathrm{mg} / \mathrm{BAP}+0.5 \mathrm{mg} / \mathrm{NAA}$. In the combination of BAP + IAA the highest weight $(4.10 \mathrm{~g})$ of PLBs was obtained from $2.0 \mathrm{mg} / \mathrm{BAP}+2.0$ $\mathrm{mg} / \mathrm{IAA}$ and lowest $(2.78 \mathrm{~g})$ from $0.5 \mathrm{mg} / \mathrm{BAP}+0.5 \mathrm{mg} / \mathrm{IAA}$. Among all combinations of growth regulators, the highest weight of PLBs $(5.53 \mathrm{~g})$ recorded from $1.0 \mathrm{mg} / \mathrm{BAP}+1.5 \mathrm{mg} / \mathrm{NAA}$. Results indicated that out of all combinations $1.0 \mathrm{mg} / \mathrm{BAP}+1.5 \mathrm{mg} / \mathrm{NAA}$ showed suitable results on proliferation of PLBs. This results are in agreement with the findings of Khatun et al. (2010) where they reported that $1.0 \mathrm{mg} / \mathrm{BAP}+\mathrm{IBA}$ is the best for PLB's proliferation. In case of protocorms development, the highest number of regenerated plantlets 

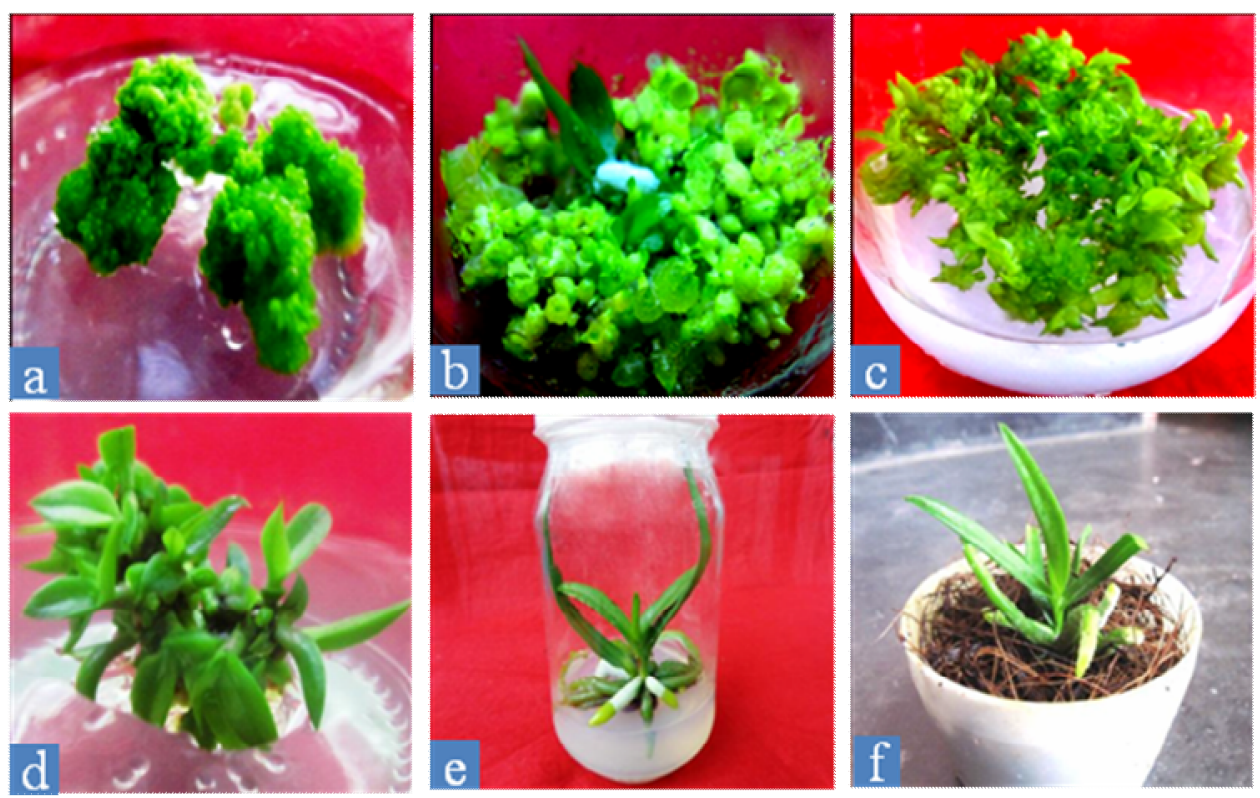

Fig. 2(a-f): Protocorm development and mass multiplication of Vanda tessellata. a. Proliferation of protocorm after 5 - 6 weeks. b-c. Secondary protocorms derived from primary PLBs. d. Plantlets development from PLBs. e. Well rooted plants; f. Plants transferred to pot after 90 days.

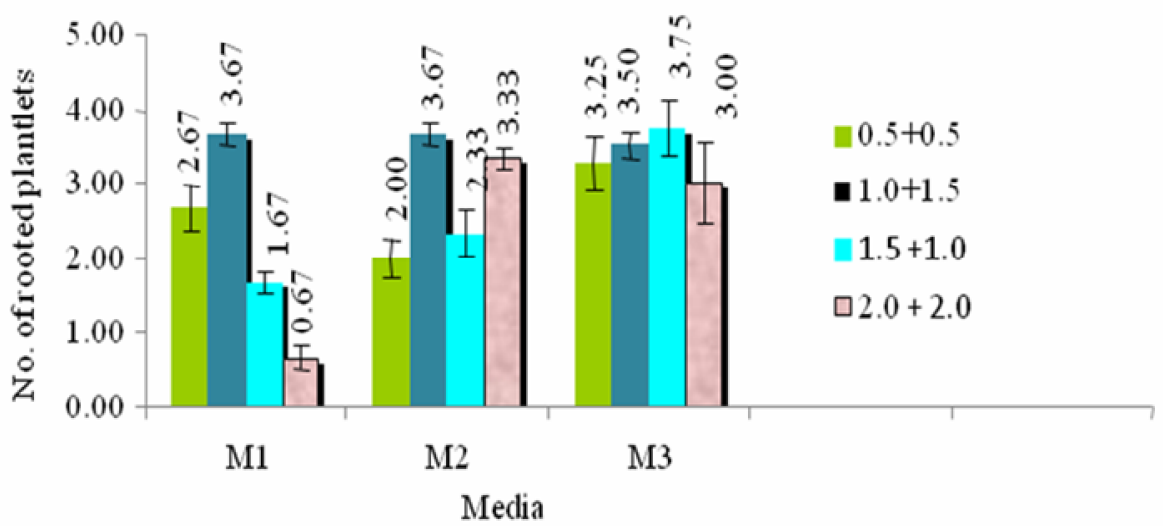

Fig. 3. Effect of different concentrations of BAP + Kn (M1), BAP + NAA (M2) and BAP + IAA (M3) on the basis of well rooted plantlets.

(16.50) was obtained in the medium fortified with $1.0 \mathrm{mg} / \mathrm{BAP}+1.5 \mathrm{mg} / \mathrm{NAA}$ followed by BAP + NAA (13.88) at a concentration of $(1.5+1.0) \mathrm{mg} /$ (Table 2). On the other hand, the lowest number (10.33) of regenerated plantlets was obtained in the medium supplemented with $2.0 \mathrm{mg} / \mathrm{BAP}+2.0 \mathrm{mg} / \mathrm{Kn}$. Such results are in agreement with the findings of Khatun et al. (2010) where they 
reported the highest number of regenerated plantlets was found in $0.5 \mathrm{mg} / \mathrm{IAA}$ $+1.0 \mathrm{mg} / \mathrm{IBA}$. The combined effect at different combinations and concentrations of growth regulators on shoot height showed a significant difference. The highest shoot height $(3.25 \mathrm{~cm})$ was obtained in the medium fortified with $1.0 \mathrm{mg} / \mathrm{BAP}$ $+1.5 \mathrm{mg} / \mathrm{NAA}$ followed by $1.0 \mathrm{mg} / \mathrm{BAP}+1.5 \mathrm{mg} / \mathrm{Kn}$ (Table 2). Similar type of observation was made by Prasad et al. (2001). They found that the highest mean shoot height was obtained on MS supplemented with $1.0 \mathrm{mg} /$ each of BAP + NAA.

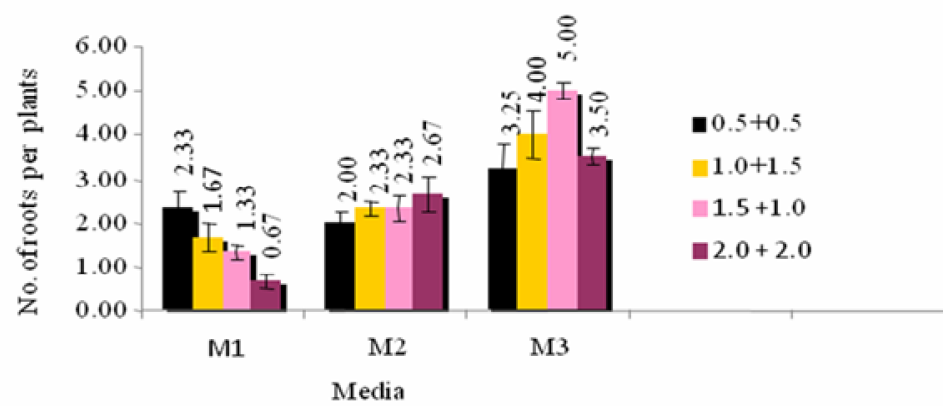

Fig. 4. Number of roots per plants using different concentrations of BAP + Kn (M1). BAP + NAA (M2) and BAP + IAA (M3) in half strength of MS.

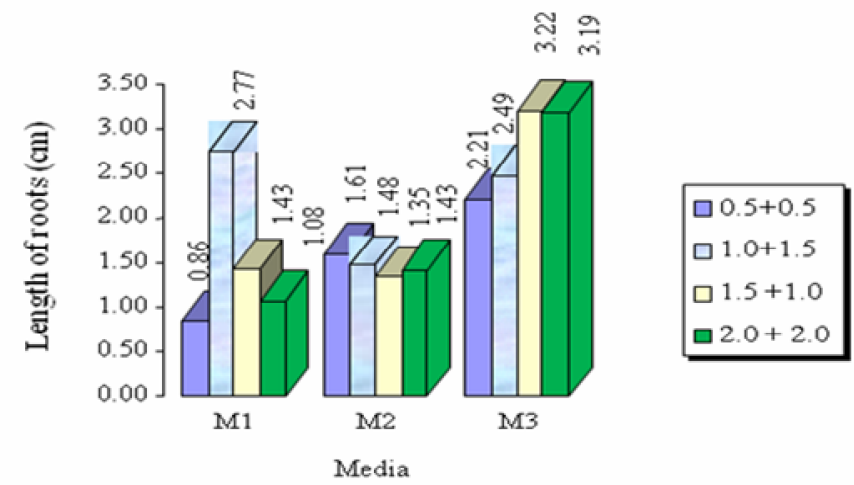

Fig. 5. Development of roots using various concentrations of BAP $+\mathrm{Kn}(\mathrm{M} 1), \mathrm{BAP}+\mathrm{NAA}$ (M2) and BAP+IAA (M3) in half strength of MS.

The number of leaves per plantlet showed a significant variation at various combinations of growth regulators. The highest number (3.33) of leaves was observed in the combination of $1.5 \mathrm{mg} / \mathrm{BAP}+1.0 \mathrm{mg} / \mathrm{IAA}$ and the lowest (1.25) number in the medium with $0.5 \mathrm{mg} / \mathrm{BAP}+0.5 \mathrm{mg} / \mathrm{Kn}$ (Fig. 6). Similarly, 
the highest length of leaves $(2.59 \mathrm{~cm})$ was obtained in the medium fortified with $2.0 \mathrm{mg} /$ each of BAP + IAA and the lowest $(0.96 \mathrm{~cm})$ was recorded on $0.5 \mathrm{mg} /$ $\mathrm{BAP}+0.5 \mathrm{mg} / \mathrm{Kn}$ (Fig. 7). A significant difference found on number of rooted plantlets among the combined effect of different combination and concentration

Table 3. Establishment of plants after 90 days in pots.

\begin{tabular}{|c|c|c|c|c|}
\hline Category & $\begin{array}{l}\text { Composition of } \\
\text { substratum }\end{array}$ & $\begin{array}{l}\text { No. of } \\
\text { plants }\end{array}$ & $\begin{array}{l}\text { Survival } \\
\text { rate }(\%)\end{array}$ & $\begin{array}{l}\text { Plant ht. } \\
\quad(\mathrm{cm})\end{array}$ \\
\hline \multirow[b]{2}{*}{ I } & Brick $+\operatorname{charcoal}(1: 1)+\operatorname{moss}(10.0$ gm/pot $)$ & 50 & 50.0 & 2.6 \\
\hline & $\begin{array}{l}\text { Brick + charcoal + decaying litter }(1: 1: 1)+ \\
\text { moss }(10.0 \text { gm/pot })\end{array}$ & 40 & 70.0 & 4.5 \\
\hline \multirow{3}{*}{ II } & $\begin{array}{l}\text { Brick + charcoal + decaying litter + saw } \\
\text { dust }(1: 1: 1: 1)+\text { moss }(10.0 \text { gm/pot })\end{array}$ & 50 & 52.0 & 3.2 \\
\hline & $\begin{array}{l}\text { Brick }+ \text { charcoal }+ \text { decaying litter }+ \text { coconut } \\
\text { husk }(1: 1: 1: 1)+\text { moss }(10.0 \text { gm/pot })\end{array}$ & 45 & 80.0 & 5.2 \\
\hline & $\begin{array}{l}\text { Brick }+ \text { charcoal }+ \text { decaying litter }+ \text { cow dung } \\
(1: 1: 1: 1)+\text { moss }(10.0 \text { gm/pot })\end{array}$ & 40 & 60.0 & 3.5 \\
\hline
\end{tabular}

Each pot diameter was $8.0 \mathrm{~cm}$.

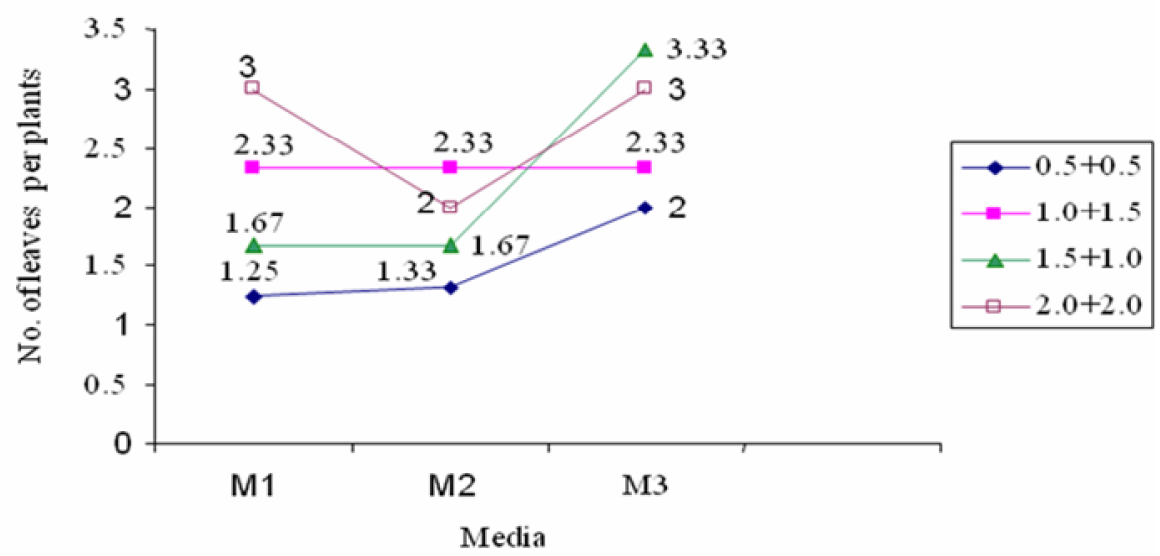

Fig. 6. Leaves per plant using various concentrations of BAP + Kn (M1), BAP + NAA (M2) and BAP + IAA (M3) in half strength of MS.

of PGRs. The highest number (3.75) of rooted plantlets was observed in the medium supplemented with $1.5 \mathrm{mg} / \mathrm{BAP}+1.0 \mathrm{mg} / \mathrm{IAA}$ and the lowest $(0.67)$ was recorded in the medium fortified with $2.0 \mathrm{mg} / \mathrm{BAP}+2.0 \mathrm{mg} / \mathrm{Kn}$ (Fig. 3). On the other hand, the highest number of roots (5.00) was obtained in the medium supplemented with $1.5 \mathrm{mg} / \mathrm{BAP}+1.0 \mathrm{mg} / \mathrm{IAA}$ and the highest length 
(3.22) of root was found in the medium fortified with $1.5 \mathrm{mg} / \mathrm{BAP}+1.0 \mathrm{mg} /$ IAA (Figs. 4, 5). Bektas et al. (2013) reported that $0.25 \mathrm{mg} / 6-\mathrm{BA}$ is suitable for promoting shoot lengths and their number and lengths of roots. On the contrary, Erisen et al. (2011) reported that TDZ was the most effective plant growth regulator for in vitro shoot formation. The findings from the present study suggest that the combination of BAP + NAA is the best for protocorm regeneration and for shoot elongation as well as mass multiplication. They reported that individually NAA had no effect but the combination of BAP + NAA produced maximum effect on development and differentiation of PLBs in Cymbidium. It might be due to their effect on physiological processes or interaction between the two hormones. On the other hand, the combined effect of $\mathrm{BAP}+\mathrm{IAA}$ is found suitable for root development (Fig. 2e). The different composts used for hardening of in vitro grown plantlets of $V$. tessellata were found to be satisfactory for the survival and normal growth of the plantlets. However, the highest percentage of surviving plants (80.0) with maximum height $(5.2 \mathrm{~cm})$ of $V$. tessellata hardened plants was obtained on a substratum containing in type II: brick, charcoal, decaying litter, coconut husk $(1: 1: 1: 1)$ with a layer of moss (Table 3, Fig. 2f). The layer of moss on top proved to be

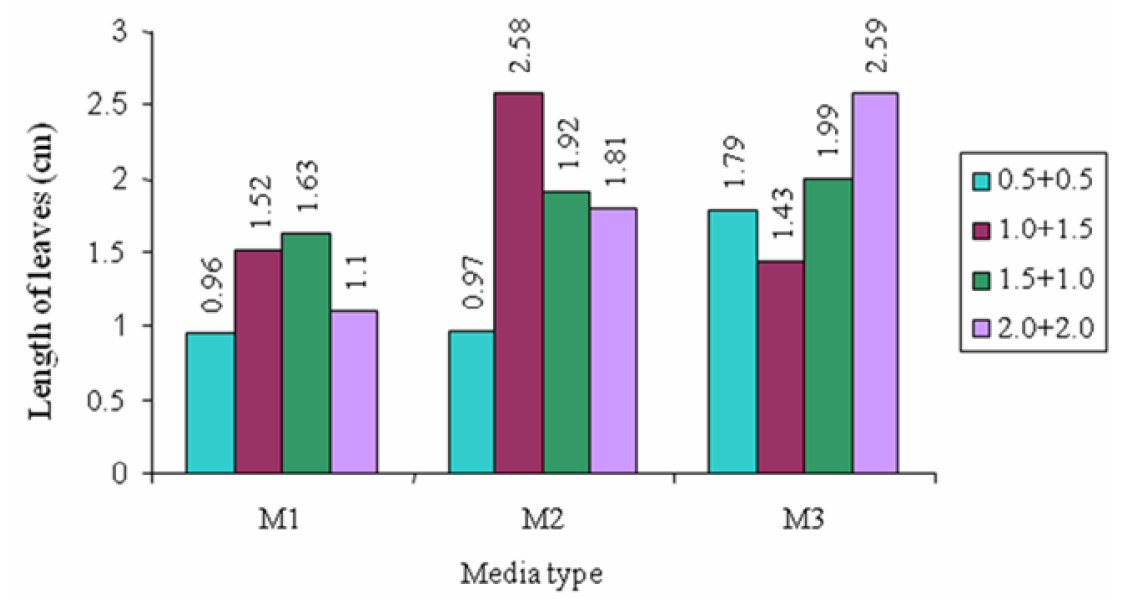

Fig. 7. Evaluation of length of leaves $(\mathrm{cm})$ by the effect of different concentrations of BAP + Kn (M1), BAP + NAA (M2) and BAP + IAA (M3) in half strength of MS.

beneficial for higher retention of the moisture content. Feeding the plantlets with a dilute solution of MS was found beneficial to the developing hardened plantlets of $V$. tessellata. This protocol of protocorm regeneration, shoot formation and ex vitro establishment of $V$. tessellata can be effectively used for its mass multiplication on a commercial scale ensuring its conservation. 
In conclusion, the above findings showed that MS is the best for seed germination and protocorm formation. Similarly MS supplemented with BAP (1.0 $\mathrm{mg} \Lambda)$ and NAA $(1.5 \mathrm{mg} \Lambda)$ was found to be the most suitable for PLBs development and plantlet formation. On the other hand, the combined effect of BAP and IAA was the suitable hormonal combination for root development. Thus, the results clearly demonstrated that the above culture condition was the most effective for mass multiplication of Vanda tessellata and this protocol will be useful to commercial growers for mass multiplication.

\section{Acknowledgements}

The authors are grateful to the authorities of the Institute of Biological Sciences, University of Rajshahi and the University Grant Commission (UGC) of Bangladesh for providing a fellowship each to the junior authors enabling them to undertake this study.

\section{References}

Antony JJJ, Sundarasekar J, Rathinam X, Marimuthu K and Subramaniam S (2014) Microscopical analysis of in vitro Mokara Broga Giant orchid's PLBs. Emir. J. Food Agric. 26 (1): 73-81.

Bektaş E, Cüce M and Sökmen A (2013) In vitro germination, protocorm formation, and plantlet development of Orchis coriophora (Orchidaceae), a naturally growing orchid species in Turkey. Turk J. Bot. 37: 336-342.

Bhadra SK, Bhattacherjee B, Barua AK and Hossain MM (2002) Micropropagation of Dendrobium aphyllum (Roxb). Bangladesh J. Genet. Biotechnol. 3: 47-50.

Chauhan NS (1999) Medicinal and Aromatic Plants of Himachal Pradesh. Indus Publishing Company, New Dehli, India.

Chugh SS, Guha and Rao IU (2009) Micropropagation of orchids: A review on the potential of different explants. Scientia Horticult. 122 (4): 507-520.

Das MC, Kumaria S and Tandon P (2007) Protocorm regeneration, multiple shoot induction and ex vitro establishment of Cymbidium devonianum Paxt. Asian J. Plant Sci. 6(2): 349-353.

Erişen S, Atalay E and Yorgancilar M (2011) The effect of thidiazuron on the in vitro shoot development of endemic Astragalus cariensis in Turkey. Turk J. Bot. 35: 521-526.

Gamborg OL, Miller A and Ojima K (1968) Nutrient requirements of suspension cultures of soyabean root cells. Exp. Cell Res. 50(1): 151-158.

Ghani A, Rastogi R and and Mehrota BN (1990) Compendium of Indian Medicinal plants. Vol. V, CDRI Lucknow and National Institute of science and communication. p. 757.

Kalimuthu K, Senthilkumar R and Vijayakumar S (2007) In vitro micropropagation of orchid, Oncidium sp. (Dancing Dolls). Afr. J. Biotechnol. 6(10): 1171-1174. 
Khatun H, Khatun MM, Biswas MS, Kabir MR and Amin MA (2010) In vitro growth and development of Dendrobium hybrid orchid. Bangladesh J. Agri. Res. 35(3): 507514.

Nongdam P and Chongtham N (2011) In vitro rapid propagation of Cymbidium aloifolium (L.) Sw.: A medicinally important orchid via seed culture. J. Biol. Sci. 11(3): 254-260.

Pierik RLM (1987) In vitro culture of higher plants. Martinus Higoff Publication. Netherlands. p. 344.

Pradhan UC (1985) Red data sheet on Indian Orchidaceae-I Vanda coerulea Griff. ex. Lindl. Indian Orchid J. 54(1).

Prasad GVSS, Rao IVS and Reddy PV (2001) In vitro propagation of orchid. Dendrobium cv. Sonia. Indian J. Plant Physiol. 6(3): 284-288.

Rahman MS, Hasan MF, Das R, Hossain MS and Rahman M (2009) In vitro micropropagation of orchid (Vanda tessellata L.) from shoot tip explants. J. Bio-Sci. Bangladesh 17: 139-144.

Singh F (1992) In vitro propagation of orchids 'A state of art report', J. Orchid Soc. India. 6:11-14.

Singh MK, Sherpa AR, Hallan V and Zaidi AA (2007) A potyvirus in Cymbidium spp. in Northern India. Australasian Plant Dis. Notes 2:11-13.

Subramoniam A, Gangaprasad A, Sureshkumar, Radhika J and Arun BK (2013) A novel aphrodisiac compound from an epiphytic orchid that activates nitric oxide synthases'. Int. J. Import. Res. 25(6): 212-6. 